\title{
Light-Assisted Batch Injection Analysis of Glucose Exploiting a p-n-Homojunction Based on $\mathrm{Cu}_{2} \mathrm{O}$
}

\author{
Elenilse R. Cardoso, ${ }^{a}$ Alan S. de Menezes, ${ }^{b}$ Clenilton C. dos Santos, ${ }^{b}$ Rita de Cássia S. Luz ${ }^{\circledR * a}$ and \\ Flávio S. Damos ${ }^{\circledR *} * a$ \\ ${ }^{a}$ Departamento de Química, Universidade Federal do Maranhão (UFMA), 65080-805 São Luís-MA, Brazil \\ ${ }^{b}$ Departamento de Física, Universidade Federal do Maranhão (UFMA), 65080-805 São Luís-MA, Brazil
}

\begin{abstract}
This work describes the development of a photoelectrochemical sensor for glucose quantification exploiting a light assisted-batch injection analysis (BIA) cell. A light-emitting diode (LED) lamp was employed to control the incidence of light on the $\mathrm{p}-\mathrm{Cu}_{2} \mathrm{O} / \mathrm{n}-\mathrm{Cu}_{2} \mathrm{O} /$ fluorine-doped tin oxide (FTO) photoactive platform in BIA cell. The $\mathrm{p}-\mathrm{Cu}_{2} \mathrm{O} / \mathrm{n}-\mathrm{Cu}_{2} \mathrm{O} / \mathrm{FTO}$ platform was constructed by electrodepositing $n-\mathrm{Cu}_{2} \mathrm{O}$ and $\mathrm{p}-\mathrm{Cu}_{2} \mathrm{O}$ and the characteristics of electrodeposited $\mathrm{Cu}_{2} \mathrm{O}$ films were investigated by X-ray diffraction (XRD), Raman spectroscopy, and electrochemical impedance spectroscopy. The light assisted-batch injection analysis of glucose based on the illuminated $\mathrm{p}-\mathrm{Cu}_{2} \mathrm{O} / \mathrm{n}-\mathrm{Cu}_{2} \mathrm{O} / \mathrm{FTO}$ photoelectrode presented a linear response of $10 \mu \mathrm{mol} \mathrm{L} \mathrm{L}^{-1}-1 \mathrm{mmol} \mathrm{L} \mathrm{m}^{-1}$, a limit of detection of $4.0 \mu \mathrm{mol} \mathrm{L}{ }^{-1}$, and sensitivity of $0.768 \pm 0.011 \mu \mathrm{A} \mathrm{L} \mu \mathrm{mol}^{-1} \mathrm{~cm}^{-2}$. The system presented an average recovery value of $96 \%$ when applied to the determination of glucose in an artificial saliva sample, which indicates that the incidence of light on photoelectroactive platforms is a promising approach for the determination and quantification of glucose.
\end{abstract}

Keywords: batch injection analysis, copper(II) oxide, glucose, LED light

\section{Introduction}

Glucose is an essential monosaccharide for the proper functioning of living organisms. ${ }^{1}$ Nevertheless, high levels of glucose in the blood can result in the development of diabetes. ${ }^{2,3}$ Diabetes is one of the most expressive causes of mortality nowadays, and it is linked to the development of several pathologies. ${ }^{4}$ In this sense, the development of sensitive and reliable glucose detection devices is of high importance, and different approaches have been developed with this aim, including methods based on chromatography, ${ }^{5}$ colorimetry, ${ }^{6}$ spectroscopy ${ }^{7}$ and sensors. ${ }^{8-10}$

Nowadays the development of enzymatic and non-enzymatic sensors for glucose detection have received high attention due to its exquisite properties. On the one hand, enzymatic glucose sensors are mainly based on the immobilization of the enzyme glucose oxidase (GOx) on various substrates and currently they play an important role in the detection of blood glucose due to its high selectivity and sensitivity. ${ }^{11,12}$ On the other hand, non-enzymatic sensors for glucose are based on the direct electro-oxidation

*e-mail: rita.luz@ufma.br; flavio.damos@ufma.br

Editor handled this article: Rodrigo A. A. Muñoz (Associate) of glucose on the surface of a catalyst. Therefore, nonenzymatic sensors for glucose do not require the use of enzymes which contribute to the stability, simplicity and reproducibility of the platforms developed for glucose detection. ${ }^{13}$ Among the several classes of sensors recently proposed for glucose determination, the electrochemical methods appear as an inexpensive, fast, accurate, sensitive, and portable, being a low-cost and straightforward alternative to measure glucose levels in different types of samples. ${ }^{14}$

In the last decade, the photoelectrochemical effect in semiconductor materials has been widely explored as a transduction process for detecting and quantifying several species, ${ }^{15}$ presenting one of the highest sensitivity among the methods based on electrochemical detection. The photoelectrochemical systems have opened new perspectives in sensor area since they can operate with low noise and background current due to the separation between the excitation light source and the photocurrent detector. ${ }^{16}$

Pioneering works in the development of photoelectrochemical platforms have opened new perspectives in determination of glucose, including photoelectrochemical enzymatic systems, ${ }^{17}$ photoelectrochemical non-enzymatic systems, ${ }^{18}$ photoelectrochemical systems based on flow 
injection analysis, ${ }^{19}$ and recently photoelectrochemical systems based on batch injection analysis. ${ }^{20}$

In addition, several photoelectroactive materials, such as semiconducting-metal-oxide-based materials, because of their interesting electrical and optical properties, have been exploited, being suitable candidates for the construction of photoelectrochemical sensors. ${ }^{20}$ Among these materials, copper(I) oxide $\left(\mathrm{Cu}_{2} \mathrm{O}\right)$ has shown an impressive electrochemical catalytic activity for glucose oxidation. ${ }^{21-25}$

Cuprous(I) oxide $\left(\mathrm{Cu}_{2} \mathrm{O}\right)$ is commonly a p-type semiconductor, and it presents a direct bandgap of around $2 \mathrm{eV}$. In addition, $\mathrm{Cu}_{2} \mathrm{O}$ shows a high absorption coefficient, abundance on Earth, non-toxic behavior and low-cost manufacturing. ${ }^{26}$ Although $\mathrm{Cu}_{2} \mathrm{O}$ is naturally a p-type semiconductor, due to copper vacancies in its structure, it is possible to obtain $\mathrm{Cu}_{2} \mathrm{O}$ as an n-type semiconductor, which occurs due to oxygen deficiency in its crystalline network. ${ }^{27}$

The properties of cuprous oxide-based materials can be intensified by exploiting the homojunction based on p-type $\left(\mathrm{p}-\mathrm{Cu}_{2} \mathrm{O}\right)$ and $\mathrm{n}$-type $\left(\mathrm{n}-\mathrm{Cu}_{2} \mathrm{O}\right)$ films. Considering that the electronic affinity of the cuprous oxides $\mathrm{p}-\mathrm{Cu}_{2} \mathrm{O}$ and $\mathrm{n}-\mathrm{Cu}_{2} \mathrm{O}$ are approximately equal, junctions based on these materials can decrease the discontinuity of the conduction band along the interface. Therefore, it is possible to form a high-quality interface through a homojunction $\mathrm{p}-\mathrm{n}$ or $\mathrm{n}-\mathrm{p}$, considering that the position of the conduction and valence bands of $\mathrm{p}-\mathrm{Cu}_{2} \mathrm{O}$ and $\mathrm{n}-\mathrm{Cu}_{2} \mathrm{O}$ are close. ${ }^{28}$

The search for fast, sensitive, simple, reproductive, versatile analytical methods motivated research groups to develop methods based on self-sampling, ${ }^{20}$ such as batch injection analysis, for example, which shows attractive features, including high throughput analysis, ${ }^{29}$ easy handling system,,$^{30}$ precision, ${ }^{31}$ accuracy, ${ }^{32}$ use of small sample volumes, high sensitivity, low cost, simplicity and portability. ${ }^{33}$

Therefore, the combined use of batch injection analysis to $\mathrm{Cu}_{2} \mathrm{O}$ based photoelectrochemical platforms can provide improvement of sensitivity, precision, detectability, and improve the throughput analysis. This work aims to develop, at first time, a photoelectrochemical assisted batch-injection analysis system based on a p- $\mathrm{Cu}_{2} \mathrm{O} / \mathrm{n}-\mathrm{Cu}_{2} \mathrm{O} /$ fluorine-doped tin oxide (FTO) photoelectrode for glucose determination.

\section{Experimental}

\section{Reagents and materials}

All chemicals used in this study were analytical grade, and they were used without further purification steps.
Copper sulfate $\left(\mathrm{CuSO}_{4}\right)$, tartaric acid $\left(\mathrm{C}_{4} \mathrm{H}_{6} \mathrm{O}_{6}\right)$, copper acetate monohydrate $\left(\mathrm{Cu}\left(\mathrm{CH}_{3} \mathrm{COO}\right)_{2} \cdot \mathrm{H}_{2} \mathrm{O}\right)$, acetic acid $\left(\mathrm{CH}_{3} \mathrm{COOH}\right)$, glucose $\left(\mathrm{C}_{12} \mathrm{H}_{22} \mathrm{O}_{11}\right)$, sodium chloride $(\mathrm{NaCl})$, potassium chloride $(\mathrm{KCl})$, calcium chloride dihydrate $\left(\mathrm{CaCl}_{2} \cdot 2 \mathrm{H}_{2} \mathrm{O}\right)$, sodium bicarbonate $\left(\mathrm{NaHCO}_{3}\right)$, sodium hydroxide $(\mathrm{NaOH})$, sodium sulfate $\left(\mathrm{Na}_{2} \mathrm{SO}_{4}\right)$ and ethyl alcohol $\left(\mathrm{C}_{2} \mathrm{H}_{6} \mathrm{O}\right)$ were purchased from ISOFAR (Duque de Caxias, Rio de Janeiro, Brazil). Glass plates with a surface covered with a transparent layer of fluorine-doped tin oxide $(\mathrm{FTO})$, and potassium ferricyanide $\left(\mathrm{K}_{3}\left[\mathrm{Fe}(\mathrm{CN})_{6}\right]\right)$ were purchased from Sigma-Aldrich (St. Louis, USA). The working solutions were prepared daily with water purified in an OS100LXE system from GEHAKA Company (São Paulo, Brazil).

\section{Construction of the $\mathrm{p}-\mathrm{Cu}_{2} \mathrm{O} / \mathrm{n}-\mathrm{Cu}_{2} \mathrm{O} / \mathrm{FTO}$ photoelectro- chemical sensor}

Initially, the glass slides coated with a layer of fluorinedoped tin oxide (FTO) were extensively rinsed with water and ethanol to remove any previously adsorbed species from the FTO surface. After that, n-type and p-type $\mathrm{Cu}_{2} \mathrm{O}$ films were deposited on the FTO surface. The electrodeposition of n-type $\mathrm{Cu}_{2} \mathrm{O}$ film was performed from bath solutions containing $0.02 \mathrm{~mol} \mathrm{~L}^{-1} \mathrm{Cu}\left(\mathrm{CH}_{3} \mathrm{COO}\right)_{2} \cdot \mathrm{H}_{2} \mathrm{O}$ and $0.08 \mathrm{molL}^{-1} \mathrm{CH}_{3} \mathrm{COOH}$. The $\mathrm{pH}$ of the medium was adjusted to 4.9 with $\mathrm{NaOH}$ solution, and the FTO working electrode was biased at $+0.02 \mathrm{~V} v s$. $\mathrm{Ag} / \mathrm{AgCl}$ for $1200 \mathrm{~s}$ at a temperature of about $70{ }^{\circ} \mathrm{C} .{ }^{34}$ On the other hand, p-type $\mathrm{Cu}_{2} \mathrm{O}$ films were electrodeposited from a plating solution containing $0.1 \mathrm{molL}^{-1} \mathrm{CuSO}_{4}$ and $0.1 \mathrm{molL}^{-1}$ tartaric acid. After adjusting the $\mathrm{pH}$ to 11 with $\mathrm{NaOH}$ solution, the temperature of the electrodeposition bath was maintained at about $60^{\circ} \mathrm{C}$ with aid of a hotplate equipped with ceramic surface from Kasvi (São José dos Pinhais, Brazil) and monitored with a thermometer, and the electrochemical platform was biased at $-0.4 \mathrm{~V} v s$. $\mathrm{Ag} / \mathrm{AgCl}$ during $300 \mathrm{~s}$ to produce the $\mathrm{p}-\mathrm{Cu}_{2} \mathrm{O}$ modified photoelectrodes. ${ }^{34,35}$

Raman, X-ray diffraction and (photo)electrochemical measurements

Raman measurements were performed with a HoribaJobin-Yvon triple spectrometer, model T64000 (Kyoto, Japan), operating in the single-mode and equipped with a liquid- $\mathrm{N}_{2}$-cooled charge-coupled device detector. A green $532 \mathrm{~nm}$ line from a solid-state laser (LAS-532-100 HREV) operating at $14 \mathrm{~mW}$ was employed for excitation, and the slit was adjusted to give a resolution of $2 \mathrm{~cm}^{-1}$. An Olympus microscope with an MPLN 50x objective lens was employed to adjust the light beam on the 
photoelectrochemical platforms. The intensity of the laser on the photoelectrochemical platform was adjusted with an ND 0.6 optical density filter ( $25 \%$ transmission). The spectra of the samples were obtained after 5 acquisitions of $30 \mathrm{~s}$ each at each range of the grade spectral dispersion.

The X-ray diffractograms (XRD) were performed with a Bruker D8 Advance diffractometer (Bruker AXS, Karlsruhe, Germany), equipped with the LynxEye linear detector, using $\mathrm{Cu} \mathrm{K \alpha}(\lambda=1.5406 \AA)$ operating at $40 \mathrm{kV}$ and a current of $40 \mathrm{~mA}$. The X-ray diffractograms were performed in a $2 \theta$ ranging from $25-75^{\circ}$ with a counting time of $0.5 \mathrm{~s}$, step size of $0.02^{\circ}$ and Bragg-Brentano geometry.

The photocurrent measurements were performed with a potentiostat/galvanostat model PGSTAT $128 \mathrm{~N}$ from Metrohm Autolab BV (Utrecht, Netherlands). A light assisted batch injection analysis cell with a photoelectrochemical platform as working electrode, a platinum wire as counter electrode and an $\mathrm{Ag} / \mathrm{AgCl}_{\text {(sat) }}$ as reference electrode was employed for photoelectrochemical measurements. The batch injection analysis cell is composed of the glass cell and a cover with three orifices for the reference electrode, counter-electrode and micropipette, and a support for the positioning of the working electrode (Figure 1).

\section{(a) (b)}

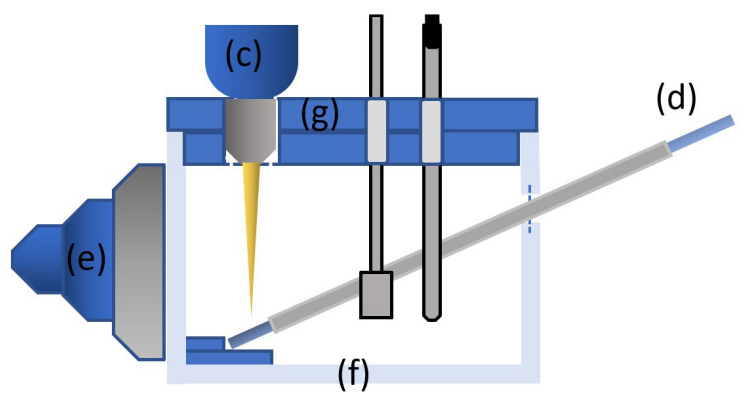

Figure 1. Photoelectrochemical batch injection analysis (PEC-BIA) cell for the electrochemical determination of glucose. (a) Auxiliary-electrode; (b) reference electrode; (c) micropipette tip; (d) photoelectrode; (e) LED lamp; (f) glass cell; and (g) 3D-printed cell cover.

The cell body was made of glass ( $5 \mathrm{~mm}$ thick), with dimensions of $7 \mathrm{~cm} \times 6 \mathrm{~cm}$. The 3D printed cover of the cell, the electrode holder and the injector holder were printed in a MakerBot Mini Plus 3D printer (Makerbot, Boston MA, USA) using the poly(acetic acid) biodegradable (PLA) filament as printing material while maintaining the extruder temperature at about $215^{\circ} \mathrm{C}$. The injections of the glucose solutions were performed with aid of an electronic micropipette model Pipetman from Gilson (Middleton, USA) operating with a fixed dispensing rate of $6 \mu \mathrm{L} \mathrm{s}^{-1}$ and an injection volume of $25 \mu \mathrm{L}$.

The $\mathrm{p}-\mathrm{Cu}_{2} \mathrm{O} / \mathrm{n}-\mathrm{Cu}_{2} \mathrm{O} / \mathrm{FTO}$ platform was employed for glucose determination in artificial saliva samples (Ringer's solution) in order to evaluate the applicability of the lightassisted photoelectrochemical batch injection analysis (PEC-BIA) system. ${ }^{36}$ The artificial saliva samples (Ringer's solution) were prepared in water with the following constituents and final concentrations: $9.0 \mathrm{~g} \mathrm{~L}^{-1} \mathrm{NaCl}$ (or ca. $0.150 \mathrm{~mol} \mathrm{~L}^{-1}$ ); $0.4 \mathrm{~g} \mathrm{~L}^{-1} \mathrm{KCl}$ (or ca. $0.005 \mathrm{~mol} \mathrm{~L}^{-1}$ ); $0.2 \mathrm{~g} \mathrm{~L}^{-1} \mathrm{CaCl}_{2} \cdot 6 \mathrm{H}_{2} \mathrm{O}$ (or ca. $0.001 \mathrm{~mol} \mathrm{~L}^{-1}$ ), and $0.2 \mathrm{~g} \mathrm{~L}^{-1}$ $\mathrm{NaHCO}_{3}$ (or $0.002 \mathrm{~mol} \mathrm{~L}^{-1}$ ). The medium's $\mathrm{pH}$ was adjusted to 7.4 with $10 \%(\mathrm{v} / \mathrm{v}) \mathrm{HCl}$ solution. ${ }^{36}$ After preparation, the solution was stored under refrigeration (ca. $4{ }^{\circ} \mathrm{C}$ ). The artificial saliva samples were diluted to $10 \%(\mathrm{v} / \mathrm{v})$ in $0.1 \mathrm{~mol} \mathrm{~L}^{-1} \mathrm{NaOH}$ electrolyte and fortified with appropriate amounts of glucose before the photoelectrochemicallyassisted batch injection analysis (PEC-BIA) measurements.

The electrochemical impedance spectroscopy (EIS) measurements were carried out in order to evaluate the electrochemical properties of the photoelectrodes. The EIS measurements were performed with the aid of an Autolab PGSTAT 128N Potentiostat/Galvanostat (Metrohm Autolab B. V. Utrecht, Netherlands) equipped with an FRA 2 module controlled by FRA software (version 4.9). The Mott-Schottky (M-S) analysis and Bode-phase measurements were performed in $0.1 \mathrm{molL}^{-1}$ sodium sulfate. The effect of the light on the electrochemical behavior of the photoelectrochemical platforms was evaluated in $0.1 \mathrm{~mol} \mathrm{~L}{ }^{-1} \mathrm{NaOH}$ containing $1000 \mu \mathrm{mol} \mathrm{L}^{-1}$ of glucose. The Nyquist and Bode plots were recorded from $10^{-1}$ to $10^{5} \mathrm{~Hz}$ under an AC amplitude of $0.01 \mathrm{~V}$. The M-S measurements were performed changing the applied potential to the photoelectrode, maintaining the frequency constant. The electrochemical characterization of the photoelectrochemical platforms was also performed by cyclic voltammetry.

\section{Results and Discussion}

Raman and XRD characterization of the photoelectrochemical platforms

Figure 2 shows the Raman spectra for electrodeposited n- $\mathrm{Cu}_{2} \mathrm{O} / \mathrm{FTO}$, p- $\mathrm{Cu}_{2} \mathrm{O} / \mathrm{FTO}$, and p- $\mathrm{Cu}_{2} \mathrm{O} / \mathrm{n}-\mathrm{Cu}_{2} \mathrm{O} / \mathrm{FTO}$. As can be seen, similar spectra were obtained for all samples. According to the literature, ${ }^{37-42}$ all the observed phonon modes are characteristic of the crystalline $\mathrm{Cu}_{2} \mathrm{O}$, with cubic symmetry belonging to the space group $\operatorname{Pn}{ }^{5} \mathrm{~m}\left(\mathrm{O}_{\mathrm{h}}{ }^{4}\right)$. Although just one Raman-active mode with symmetry $\Gamma_{25}^{+}$is expected in the Raman spectrum for this structure, infrared (with symmetries $\Gamma_{15}^{-(1)}$ and $\Gamma_{15}^{-(2)}$ ) and selectionruler-forbidden modes, such as the modes with symmetries $\Gamma_{12}^{-}$and $\Gamma_{25}^{-}$, can also be allowed due to local defects and intrinsic selection rule violation mechanism, which explains the presence of the extra modes. Therefore, we attributed the 
peak at about $149 \mathrm{~cm}^{-1}$ as being from an infrared-allowed phonon mode with symmetry $\Gamma_{15}^{-(1)}$, the peak at $198 \mathrm{~cm}^{-1}$ as due to a two-phonon combination mode of $\Gamma_{12}^{-}$and $\Gamma_{25}^{-}$, and the intense line at about $218 \mathrm{~cm}^{-1}$ from the second-order overtone of the phonon with symmetry $\Gamma_{12}^{-}\left(2 \Gamma_{12}^{-}\right) .^{37-40}$
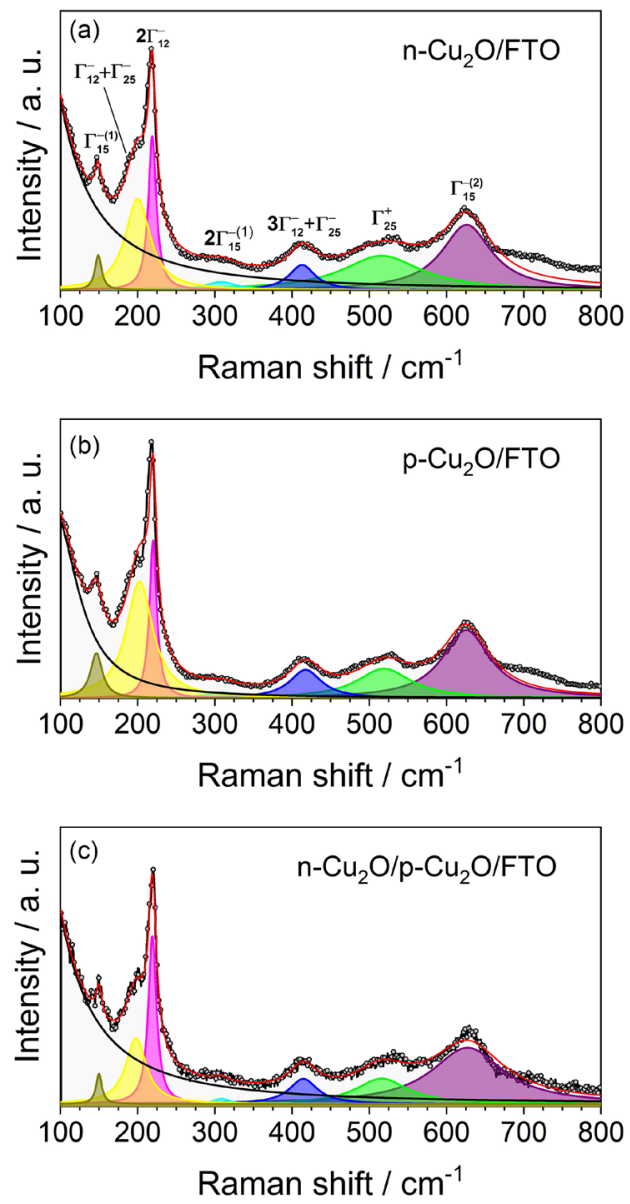

Figure 2. Raman spectra for the $\mathrm{n}-\mathrm{Cu}_{2} \mathrm{O} / \mathrm{FTO}$ (a), p- $\mathrm{Cu}_{2} \mathrm{O} / \mathrm{FTO}$ (b) and $\mathrm{p}-\mathrm{Cu}_{2} \mathrm{O} / \mathrm{n}-\mathrm{Cu}_{2} \mathrm{O} / \mathrm{FTO}$ (c) platforms.

In addition, the weak peaks at about $308 \mathrm{~cm}^{-1}$ correspond to the second-order overtone mode $2 \Gamma_{15}^{-(1)},{ }^{34}$ the peak at $414 \mathrm{~cm}^{-1}$ is assigned to a four-phonon mode $3 \Gamma_{12}^{-}+\Gamma_{25}^{-}{ }^{41}$ the peak at about $516 \mathrm{~cm}^{-1}$ is the Raman-active mode $\left(\Gamma_{25}^{+}\right),{ }^{41,42}$ and the signal at $626 \mathrm{~cm}^{-1}$ is attributed to the infraredallowed mode $\Gamma_{15}^{-(2)} \cdot{ }^{41}$

The X-ray diffraction patterns of all the $\mathrm{Cu}_{2} \mathrm{O}$ samples electrodeposited on FTO substrate presented peaks from the cubic (Pn $\overline{3} \mathrm{~m}$ space group, PDF:00-005-0667) structure of the $\mathrm{Cu}_{2} \mathrm{O}$ as well as peaks of the FTO substrate (Figure 3 ). The XRD patterns presented peaks $(2 \theta)$ at $29.6^{\circ}, 36.5^{\circ}$, $42.4^{\circ}, 61.4^{\circ}$, and $73.6^{\circ}$ indicative of the (110), (111), (200), (220) and (311) planes, respectively, which correspond to the cubic structure of $\mathrm{Cu}_{2} \mathrm{O}$. In addition, the intensity of the peak (111) is higher than the others indicating a preferential growth of the $\mathrm{Cu}_{2} \mathrm{O}$ films along the (111) direction..$^{40-43}$

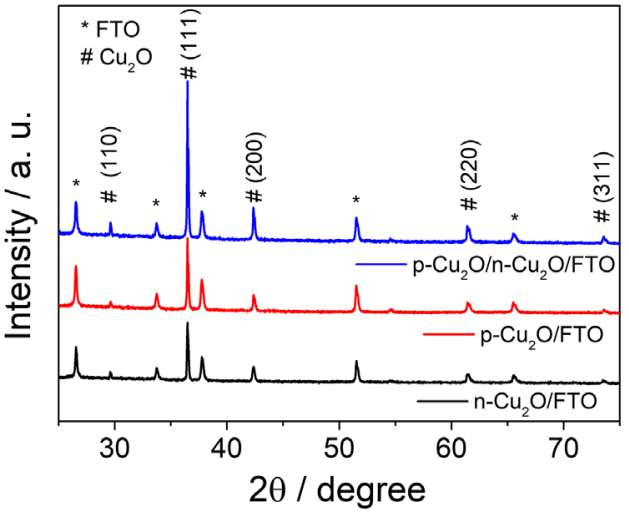

Figure 3. X-ray diffraction of the $n-\mathrm{Cu}_{2} \mathrm{O} / \mathrm{FTO}$ (black line), $\mathrm{p}-\mathrm{Cu}_{2} \mathrm{O} / \mathrm{FTO}$ (red line) and $\mathrm{p}-\mathrm{Cu}_{2} \mathrm{O} / \mathrm{n}-\mathrm{Cu}_{2} \mathrm{O} / \mathrm{FTO}$ (blue line) platforms.

Electrochemical impedance spectroscopy investigation of the photoelectrochemical platforms

Electrochemical impedance spectroscopy measurements were performed to evaluate the effects of the type of $\mathrm{Cu}_{2} \mathrm{O}$ semiconductor on the electrochemical properties of the platform. Figure 4 shows the Nyquist plots obtained for n- $\mathrm{Cu}_{2} \mathrm{O} / \mathrm{FTO}$ (Figure 4a), p- $\mathrm{Cu}_{2} \mathrm{O} /$ FTO (Figure 4b), and p- $\mathrm{Cu}_{2} \mathrm{O} / \mathrm{n}-\mathrm{Cu}_{2} \mathrm{O} / \mathrm{FTO}$ (Figure $4 \mathrm{c}$ ) in $0.1 \mathrm{~mol} \mathrm{~L}^{-1} \mathrm{NaOH}$ containing $1 \mathrm{mmol} \mathrm{L}^{-1}$ of glucose under dark (blue circle) and light (red square) conditions.

As can be seen in Figure 4, the p- $\mathrm{Cu}_{2} \mathrm{O} / \mathrm{n}-\mathrm{Cu}_{2} \mathrm{O} / \mathrm{FTO}$ presented a semicircle diameter slightly lower than that observed to the $\mathrm{n}-\mathrm{Cu}_{2} \mathrm{O} / \mathrm{FTO}$, and $\mathrm{p}-\mathrm{Cu}_{2} \mathrm{O} / \mathrm{FTO}$ photoelectrodes. In addition, the Figure 4 shows the effects of the incidence of light on the $\mathrm{p}-\mathrm{Cu}_{2} \mathrm{O} / \mathrm{FTO} / \mathrm{n}-\mathrm{Cu}_{2} \mathrm{O} / \mathrm{FTO}$ platform. The Nyquist plots of $\mathrm{p}-\mathrm{Cu}_{2} \mathrm{O} / \mathrm{n}-\mathrm{Cu}_{2} \mathrm{O} / \mathrm{FTO}$ platform were affected by the incidence of light indicating that the harvested photons can promote electrons from valence band to conduction band of the semiconductor, which can contribute to a lower charge transfer resistance at the photoelectrode-electrolyte interface. The lower diameter semicircle observed for $\mathrm{p}-\mathrm{Cu}_{2} \mathrm{O} / \mathrm{FTO} / \mathrm{n}-\mathrm{Cu}_{2} \mathrm{O} / \mathrm{FTO}$ under the incidence of light can be attributed to the more favorable electron transfer from the analyte to the holes in the $\mathrm{p}-\mathrm{Cu}_{2} \mathrm{O} / \mathrm{FTO} / \mathrm{n}-\mathrm{Cu}_{2} \mathrm{O} / \mathrm{FTO}$ platform due to a better band alignment formed in the homojunction which facilitates the action of glucose as a hole scavenger. The electrons can diffuse from the $\mathrm{n}-\mathrm{Cu}_{2} \mathrm{O}$ film to the $\mathrm{p}-\mathrm{Cu}_{2} \mathrm{O}$ probably due to the higher Fermi level of the n-type film than the Fermi level of the $\mathrm{p}-\mathrm{Cu}_{2} \mathrm{O}$ film. Similarly, the photogenerated holes can diffuse from the p-type film to the n-type film. Thus, the flow of charges carriers between the films can establish an internal electrical field at the p-n interface. The internal potential developed in the interface can improve the charge separation and charge flow at the interface, which can also contribute to a low charge resistance. 

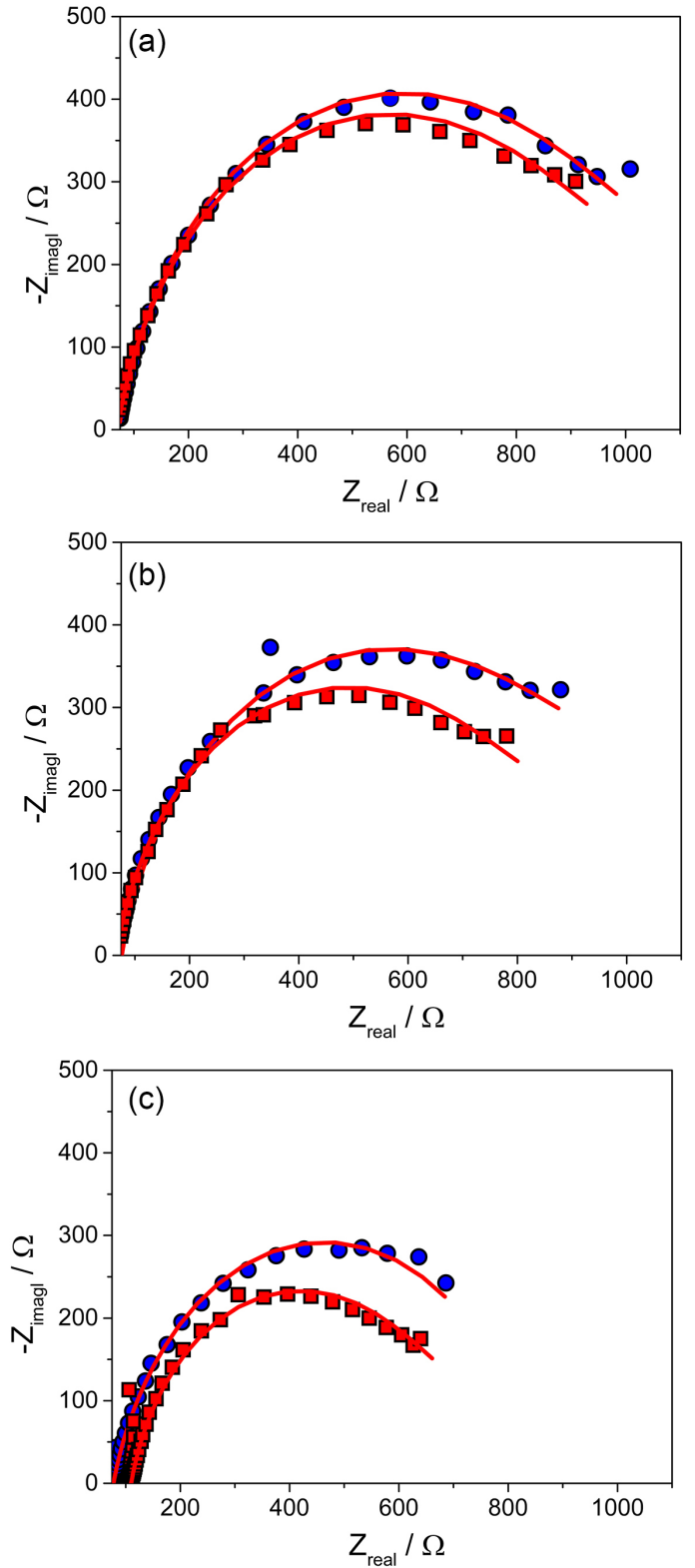

Figure 4. Nyquist plots for $\mathrm{n}-\mathrm{Cu}_{2} \mathrm{O} / \mathrm{FTO}$ (a), p- $\mathrm{Cu}_{2} \mathrm{O} / \mathrm{FTO}$ (b) and $\mathrm{p}-\mathrm{Cu}_{2} \mathrm{O} / \mathrm{n}-\mathrm{Cu}_{2} \mathrm{O} / \mathrm{FTO}$ (c) in $0.1 \mathrm{~mol} \mathrm{~L}^{-1} \mathrm{NaOH}$ aqueous solution containing $1 \mathrm{mmol} \mathrm{L}^{-1}$ of glucose under dark (blue circles) and light (red square) conditions. The red full lines represent the Nyquist semicircle fit.

Mott-Schottky plots were performed in $0.1 \mathrm{~mol} \mathrm{~L}^{-1}$ $\mathrm{Na}_{2} \mathrm{SO}_{4}$ in order to evaluate the semiconductor type (p-type or n-type) and the flat-band potential $\left(\mathrm{E}_{\mathrm{fb}}\right)$ (Figure 5). As can be seen from Figure 5a, the slope of the Mott-Schottky plot for $\mathrm{n}-\mathrm{Cu}_{2} \mathrm{O} / \mathrm{FTO}$ platform was positive while the slope of the $\mathrm{p}-\mathrm{Cu}_{2} \mathrm{O} / \mathrm{FTO}$ platform was negative indicating an n-type and p-type conductivity, respectively. On the other hand, the Mott-Schottky plot of the $\mathrm{p}-\mathrm{Cu}_{2} \mathrm{O} / \mathrm{n}-\mathrm{Cu}_{2} \mathrm{O} / \mathrm{FTO}$ platform (Figure 5b) presented co-existence of positive and negative slopes indicating that the photoelectrochemical platform presents the behavior of a p-n-junction, which is helpful for effective separation of electrons and holes. ${ }^{44}$
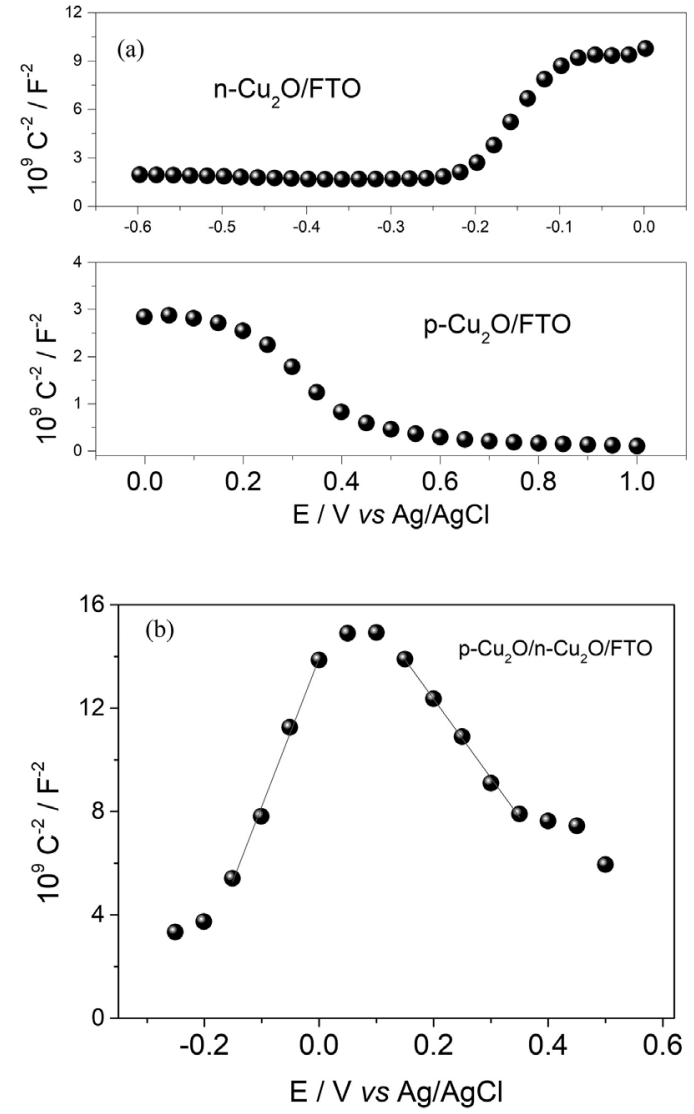

Figure 5. Mott-Schottky plots $\left(\mathrm{C}^{-2}\right.$ vs. E) for $\mathrm{n}-\mathrm{Cu}_{2} \mathrm{O} / \mathrm{FTO}$ and $\mathrm{p}-\mathrm{Cu}_{2} \mathrm{O} / \mathrm{FTO}$ (a) and p- $\mathrm{Cu}_{2} \mathrm{O} / \mathrm{n}-\mathrm{Cu}_{2} \mathrm{O} / \mathrm{FTO}$ (b) were obtained in $0.1 \mathrm{~mol} \mathrm{~L}^{-1}$ $\mathrm{Na}_{2} \mathrm{SO}_{4}$.

The Mott-Schottky plot $\left(\mathrm{C}_{\mathrm{SC}^{-2}} v s . \mathrm{E}_{\text {appl }}\right)$ were constructed according to the following equation: ${ }^{45}$

$\left(\frac{1}{\mathrm{C}_{\mathrm{SC}}}\right)^{-2}= \pm \frac{2}{\mathrm{e}_{0} \mathrm{~N}_{\mathrm{a}, \mathrm{d}} \varepsilon_{0} \varepsilon_{\mathrm{r}}}\left(\mathrm{E}_{\mathrm{appl}}-\mathrm{E}_{\mathrm{fb}}-\frac{\mathrm{k}_{\mathrm{B}} \mathrm{T}}{\mathrm{e}_{0}}\right)$

where $\mathrm{e}_{0}$ is the elementary charge of the electron, $\mathrm{N}_{\mathrm{a}, \mathrm{d}}$ is the acceptor or donor charge density, $\varepsilon_{0}$ is the vacuum permittivity, $\varepsilon_{\mathrm{r}}$ is the relative permittivity of $\mathrm{Cu}_{2} \mathrm{O}$, $\mathrm{C}_{\mathrm{SC}}$ is the capacitance of the space charge layer, $\mathrm{E}_{\mathrm{appl}}$ is the applied potential, $\mathrm{k}_{\mathrm{B}}$ is the Boltzmann's constant, $\mathrm{T}$ is the absolute temperature, and $\mathrm{E}_{\mathrm{fb}}$ is the flat band potential.

The flat band potentials of the $n-\mathrm{Cu}_{2} \mathrm{O}$ type and $\mathrm{p}-\mathrm{Cu}_{2} \mathrm{O}$ type branches of Mott-Schottky plot obtained for the $\mathrm{p}-\mathrm{Cu}_{2} \mathrm{O} / \mathrm{n}-\mathrm{Cu}_{2} \mathrm{O} / \mathrm{FTO}$ platform were determined from the intercept of the Mott-Schottky plot under flat band condition considering that $\mathrm{E}_{\mathrm{fb}}=\mathrm{E}_{\mathrm{appl}}-\frac{\mathrm{k}_{\mathrm{B}} \mathrm{T}}{\mathrm{e}_{0}}$ and $\left(\frac{1}{\mathrm{C}_{\mathrm{SC}}}\right)^{-2}=0$. The flat band potentials for $\mathrm{n}-\mathrm{Cu}_{2} \mathrm{O}$ and $\mathrm{p}-\mathrm{Cu}_{2} \mathrm{O}$ were about $-0.269 \mathrm{~V}$ and $+0.579 \mathrm{~V}$, respectively. In addition, the MottSchottky plots of $\mathrm{p}-\mathrm{Cu}_{2} \mathrm{O} / \mathrm{n}-\mathrm{Cu}_{2} \mathrm{O} / \mathrm{FTO}$ platform presented an inverted "V-shape" as shown in the Figure 5b, indicating 
the formation of $\mathrm{p}-\mathrm{n}$ junctions in the $\mathrm{p}-\mathrm{Cu}_{2} \mathrm{O} / \mathrm{n}-\mathrm{Cu}_{2} \mathrm{O} / \mathrm{FTO}$ platform. ${ }^{46-48}$

Analytical performance and application of $\mathrm{p}-\mathrm{Cu}_{2} \mathrm{O} /$ $\mathrm{n}-\mathrm{Cu}_{2} \mathrm{O} / \mathrm{FTO}$ photoelectrochemical platform for glucose determination in a PEC-BIA cell

In order to evaluate the analytical efficiency of the $\mathrm{p}-\mathrm{Cu}_{2} \mathrm{O} / \mathrm{n}-\mathrm{Cu}_{2} \mathrm{O} / \mathrm{FTO}$ photoelectrochemical platform to the glucose determination were performed successive batch injections of different concentrations of glucose with the aid of an electronic micropipette in the absence and the presence of light (Figure 6a).

As can be seen in the Figure $6 \mathrm{~b}$, the peak current increases linearly with the increase of the concentration of glucose concentrations ranging from 10 up to $1000 \mu \mathrm{mol} \mathrm{L}^{-1}$ under the incidence of visible light biasing the platform at $0.6 \mathrm{~V}$ vs. $\mathrm{Ag} / \mathrm{AgCl}$. The calibration curve obtained for glucose determination by PEC-BIA based on $\mathrm{p}-\mathrm{Cu}_{2} \mathrm{O} / \mathrm{n}$ $\mathrm{Cu}_{2} \mathrm{O} / \mathrm{FTO}$ photoelectrochemical platform presented a linear behavior according to the following equation: $\mathrm{I}_{\text {peak }} / \mu \mathrm{A}=14.643+0.768\left([\right.$ glucose $\left.] / \mu \mathrm{mol}^{-1}\right)$, for $\mathrm{n}=7$ and a correlation coefficient of 0.999 .

The light-assisted determination of glucose with PEC-BIA system presented a limit of detection (LOD) of about $4.0 \mu \mathrm{mol} \mathrm{L} \mathrm{L}^{-1}\left(\mathrm{LOD}=3 \mathrm{~s}_{\mathrm{B}} / \mathrm{S}\right.$, in which $\mathrm{s}_{\mathrm{B}}$ is the standard deviation of the blank and $\mathrm{S}$ is the slope of the calibration curve) and sensitivity of $0.768 \mu \mathrm{A} \mathrm{L} \mu \mathrm{mol}^{-1} \mathrm{~cm}^{-2}$ which is competitive when compared to some recent works (Table 1) $)^{49-54}$ for glucose detection based on copper-based platforms. On the other hand, the sensitivity of the platform in the absence of light was $0.546 \mu \mathrm{A} \mathrm{L} \mu \mathrm{mol}^{-1} \mathrm{~cm}^{-2}$ (Figure 6b).

As can be seen in the Figure $6 \mathrm{~b}$, the incidence of light on the $\mathrm{p}-\mathrm{Cu}_{2} \mathrm{O} / \mathrm{n}-\mathrm{Cu}_{2} \mathrm{O} / \mathrm{FTO}$ platform has resulted in an increase of the sensitivity of the system. The calibration
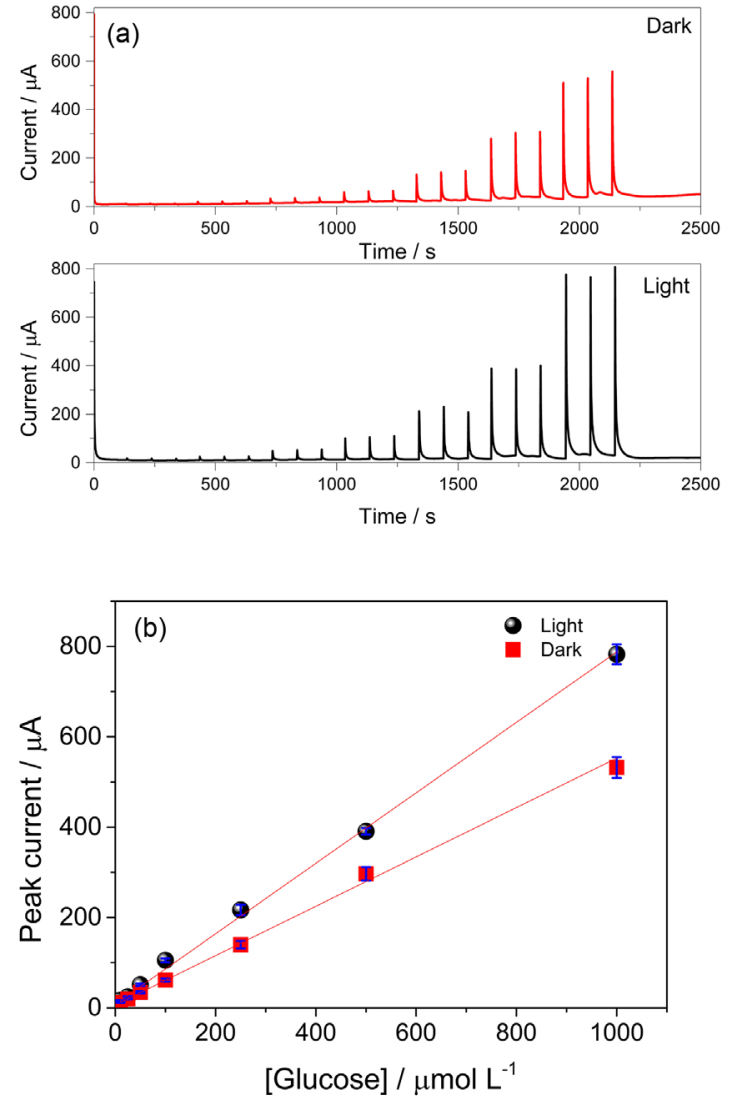

Figure 6. (a) Amperometric responses obtained after injection of glucose in the batch injection analysis system in the absence (red line) and presence of light (black line). (b) Analytical curve for glucose determination under the incidence of light (black circle) and under dark conditions (red square). Dispensing rate: $6 \mu \mathrm{L} \mathrm{s}^{-1}$; injection volume: $25 \mu \mathrm{L}$; and applied potential: $0.6 \mathrm{~V} v s . \mathrm{Ag} / \mathrm{AgCl}$.

curves for the determination of glucose with the proposed $\mathrm{p}-\mathrm{Cu}_{2} \mathrm{O} / \mathrm{n}-\mathrm{Cu}_{2} \mathrm{O} / \mathrm{FTO}$ platform shows a higher slope under the incidence of light than under dark conditions (Figure 6b). The $\mathrm{p}-\mathrm{Cu}_{2} \mathrm{O} / \mathrm{n}-\mathrm{Cu}_{2} \mathrm{O} / \mathrm{FTO}$ can generate electron-hole couples under the incidence of light in order

Table 1. Comparison of some non-enzymatic sensors for the determination of glucose

\begin{tabular}{|c|c|c|c|c|}
\hline Platform & $\begin{array}{l}\text { Response range / } \\
\left(\mathrm{mmol} \mathrm{L}^{-1}\right)\end{array}$ & $\begin{array}{c}\text { Sensitivity / } \\
\left(\mu \mathrm{A} \mathrm{L} \mathrm{mmol}^{-1} \mathrm{~cm}^{-2}\right)\end{array}$ & $\begin{array}{l}\text { Limit of detection / } \\
\left.(\mu \mathrm{mol} \mathrm{L})^{-1}\right)\end{array}$ & Reference \\
\hline Octahedral $\mathrm{Cu}_{2} \mathrm{O}$ & $0.10-5.00$ & 293.893 & 5.11 & 49 \\
\hline Cubic $\mathrm{Cu}_{2} \mathrm{O}$ & $0.10-2.50$ & 22.669 & 12.80 & 49 \\
\hline Octahedral CQDs $\mathrm{Cu}_{2} \mathrm{O} / \mathrm{Nafion} / \mathrm{GCE}$ & $0.02-4.30$ & 298 & 8.40 & 50 \\
\hline Octahedral $\mathrm{Cu}_{2} \mathrm{O}$ & $0.30-4.10$ & 241 & 128.00 & 50 \\
\hline $\mathrm{Cu}_{2} \mathrm{O} / \mathrm{GNs}$ & $0.30-3.30$ & 285 & 3.30 & 51 \\
\hline $\mathrm{Cu}_{2} \mathrm{O} / \mathrm{TNT}$ & $3.00-9.00$ & 14.56 & 62.00 & 52 \\
\hline $\mathrm{Cu} / \mathrm{Cu}_{2} \mathrm{O} / \mathrm{CS}$ & $0.01-0.69$ & 63.8 & 5.00 & 53 \\
\hline $\mathrm{Cu} / \mathrm{Cu}_{2} \mathrm{O} / \mathrm{CS}$ & $1.19-3.69$ & 22.6 & - & 53 \\
\hline $\mathrm{Au} @ \mathrm{Cu}_{2} \mathrm{O}$ & $0.05-2.00$ & 715 & 18.00 & 54 \\
\hline $\mathrm{p}-\mathrm{Cu}_{2} \mathrm{O} / \mathrm{n}-\mathrm{Cu}_{2} \mathrm{O} / \mathrm{FTO}$ & $0.01-1.00$ & 768 & 4.00 & this work \\
\hline
\end{tabular}

CQDs: carbon quantum dots; GCE: glassy carbon electrode; GNs: graphene nanosheets; TNT: $\mathrm{TiO}_{2}$ nanotubes; CS: carbon spheres; FTO: fluorine-doped tin oxide. 
to increase the sensitivity of the photoelectrochemical platform for glucose detection. Thus, the $\mathrm{p}-\mathrm{Cu}_{2} \mathrm{O} /$ $\mathrm{n}-\mathrm{Cu}_{2} \mathrm{O} / \mathrm{FTO}$ photoelectrochemical platform acts as a photoelectrochemical-assisted detector for the batch injection analysis since the electron-hole couples produced can improve the glucose oxidation.

Figure 7 shows a proposed scheme for the light assisted batch-injection analysis of glucose employing a p- $\mathrm{Cu}_{2} \mathrm{O} / \mathrm{n}-\mathrm{Cu}_{2} \mathrm{O} / \mathrm{FTO}$ photoelectrochemical platform biased at $0.6 \mathrm{~V} v s$. Ag/AgCl. The $\mathrm{p}-\mathrm{Cu}_{2} \mathrm{O} / \mathrm{n}-\mathrm{Cu}_{2} \mathrm{O} / \mathrm{FTO}$ photoelectrochemical platform harvests photons from incident light in order to produce electron-hole couples in $\mathrm{p}-\mathrm{Cu}_{2} \mathrm{O}$ and $\mathrm{n}-\mathrm{Cu}_{2} \mathrm{O}$ (equations 2 and 3 ).

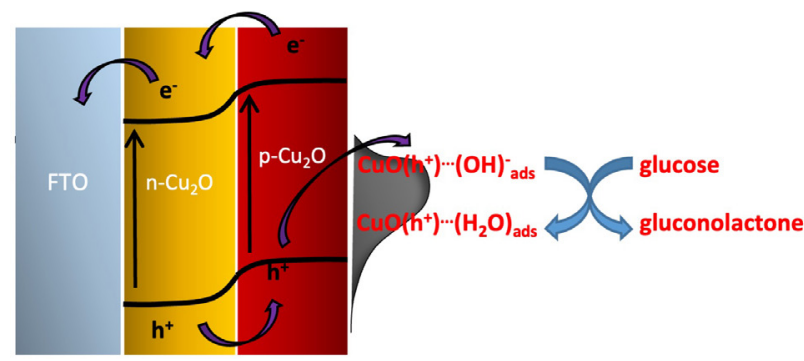

Figure 7. Schematic representation of the proposed mechanism for the oxidation of glucose on $\mathrm{p}-\mathrm{Cu}_{2} \mathrm{O} / \mathrm{n}-\mathrm{Cu}_{2} \mathrm{O} / \mathrm{FTO}$ photoelectrode surface under illumination.

The electrons photogenerated in the conduction band of $\mathrm{p}-\mathrm{Cu}_{2} \mathrm{O}$ are driven to the conduction band of $\mathrm{n}-\mathrm{Cu}_{2} \mathrm{O}$ to become further dragged by the FTO platform. Simultaneously, the holes photogenerated can be harvested by the glucose molecules at the interface photoelectrodesolution, and the holes photogenerated in $\mathrm{n}-\mathrm{Cu}_{2} \mathrm{O}$ can be transferred to the valence band of $\mathrm{p}-\mathrm{Cu}_{2} \mathrm{O}$. Considering that the $\mathrm{p}-\mathrm{Cu}_{2} \mathrm{O} / \mathrm{n}-\mathrm{Cu}_{2} \mathrm{O} / \mathrm{FTO}$ photoelectrochemical platform was biased at $0.6 \mathrm{~V}$, the $\mathrm{Cu}_{2} \mathrm{O}$ at the semiconductor/ electrolyte interface can be oxidized to form $\mathrm{CuO}$. The photogenerated holes in $\mathrm{CuO}$ can then form ion pairs with $\mathrm{OH}^{-}$with sufficient energy to promote the glucose oxidation. The following reactions are proposed for glucose oxidation on the $\mathrm{p}-\mathrm{Cu}_{2} \mathrm{O} / \mathrm{n}-\mathrm{Cu}_{2} \mathrm{O} / \mathrm{FTO}$ photoelectrochemical platform under the incidence of light:

$$
\begin{aligned}
& \mathrm{n}-\mathrm{Cu}_{2} \mathrm{O}+\mathrm{h} v \rightarrow \mathrm{e}^{-}{ }_{\mathrm{n}-\mathrm{Cu}_{2} \mathrm{O}}+\mathrm{h}^{+}{ }_{\mathrm{n}-\mathrm{Cu}_{2} \mathrm{O}} \\
& \mathrm{p}-\mathrm{Cu}_{2} \mathrm{O}+\mathrm{h} v \rightarrow \mathrm{e}^{-}{ }_{\mathrm{p}-\mathrm{Cu}_{2} \mathrm{O}}+\mathrm{h}^{+}{ }_{\mathrm{p}-\mathrm{Cu}_{2} \mathrm{O}} \\
& \mathrm{p}-\mathrm{Cu}_{2} \mathrm{O}+2 \mathrm{~h}^{+}{ }_{\mathrm{p}-\mathrm{Cu}_{2} \mathrm{O}}+2 \mathrm{OH}^{-} \rightarrow 2 \mathrm{CuO}+\mathrm{H}_{2} \mathrm{O} \\
& \mathrm{CuO}+\mathrm{hv} \rightarrow \mathrm{e}^{-}{ }_{(\mathrm{CuO})}+\mathrm{CuO}\left(\mathrm{h}^{+}{ }_{(\mathrm{CuO})}\right) \\
& \mathrm{CuO}\left(\mathrm{h}^{+}{ }_{(\mathrm{CuO})}\right)+\mathrm{OH}^{-} \rightarrow \mathrm{CuO}\left(\mathrm{h}^{+}{ }_{(\mathrm{CuO})}\right)\left(\mathrm{OH}^{-}{ }_{\text {ads }}\right) \\
& \mathrm{CuO}\left(\mathrm{h}^{+}{ }_{(\mathrm{CuO})}\right)\left(\mathrm{OH}^{-}{ }_{\text {ads }}\right)+\text { glucose } \rightarrow \mathrm{H}_{2} \mathrm{O}_{\text {ads }}+ \\
& \text { gluconolactone }
\end{aligned}
$$

The repeatability of the $\mathrm{p}-\mathrm{Cu}_{2} \mathrm{O} / \mathrm{n}-\mathrm{Cu}_{2} \mathrm{O} / \mathrm{FTO}$ photoelectrochemical platform biased at $+0.6 \mathrm{~V} v s$. $\mathrm{Ag} / \mathrm{AgCl}$ was evaluated performing successive photoelectrochemicalassisted batch injection analysis of $50 \mu \mathrm{mol} \mathrm{L}^{-1}$ of glucose. The relative standard deviation (RSD) of the response of the $\mathrm{p}-\mathrm{Cu}_{2} \mathrm{O} / \mathrm{n}-\mathrm{Cu}_{2} \mathrm{O} / \mathrm{FTO}$ photoelectrochemical platform for three successive injections of glucose was about $2.9 \%$. On the other hand, the reproducibility of the $\mathrm{p}-\mathrm{Cu}_{2} \mathrm{O} / \mathrm{n}-\mathrm{Cu}_{2} \mathrm{O} / \mathrm{FTO}$ photoelectrochemical platform for detecting glucose was about $3.5 \%$ for the photocurrents. The long-term stability of the proposed $\mathrm{p}-\mathrm{Cu}_{2} \mathrm{O} / \mathrm{n}-\mathrm{Cu}_{2} \mathrm{O} / \mathrm{FTO}$ photoelectrochemical platform was evaluated monitoring the response of the system for one month. It was observed that the $\mathrm{p}-\mathrm{Cu}_{2} \mathrm{O} / \mathrm{n}-\mathrm{Cu}_{2} \mathrm{O} / \mathrm{FTO}$ photoelectrochemical platform retained more than $95 \%$ of its initial response after one month.

The effects of some species frequently observed in formulations of artificial saliva samples on the response of the photoelectrochemical platform were investigated in order to evaluate the selectivity of the photoelectrochemicalassisted batch injection analysis of glucose exploiting the $\mathrm{p}-\mathrm{Cu}_{2} \mathrm{O} / \mathrm{n}-\mathrm{Cu}_{2} \mathrm{O} / \mathrm{FTO}$ photoelectrode. In this sense, the effects of potassium, sodium, calcium, magnesium, dihydrogen phosphate, ammonium, and chloride ions, as well as the interference of urea and amylase molecules on the response of the $\mathrm{p}-\mathrm{Cu}_{2} \mathrm{O} / \mathrm{n}-\mathrm{Cu}_{2} \mathrm{O} / \mathrm{FTO}$ photoelectrode were tested in a glucose/foreign specie ratio of $1 / 1$, respectively. Recovery tests were performed applying the $\mathrm{p}-\mathrm{Cu}_{2} \mathrm{O} / \mathrm{n}-\mathrm{Cu}_{2} \mathrm{O} /$ FTO photoelectrode in artificial saliva samples spiked with a known amount of glucose. The glucose concentration found in spiked samples was calculated using the standard addition method, and the concentration value found of $67.2 \mu \mathrm{mol} \mathrm{L}^{-1}$ was in good agreement to spiked in sample of $70 \mu \mathrm{mol} \mathrm{L}^{-1}$, having a detection recovery of $96 \%$.

\section{Conclusions}

The present work describes at the first time the development of a photoelectrochemical-assisted batch injection analysis system exploiting a homojunction based on a p- $\mathrm{Cu}_{2} \mathrm{O} / \mathrm{n}-\mathrm{Cu}_{2} \mathrm{O} / \mathrm{FTO}$ photoelectrode for glucose detection. The Raman spectra of $n-\mathrm{Cu}_{2} \mathrm{O}$ and $\mathrm{p}-\mathrm{Cu}_{2} \mathrm{O}$, electrodeposited on the FTO surface, indicated that they have the phonon frequencies characteristic of crystalline $\mathrm{Cu}_{2} \mathrm{O}$. The XRD patterns confirmed the crystalline character of the electrodeposits and that they preferentially grow along the (111). The Mott-Schottky analysis indicated that the $\mathrm{n}-\mathrm{Cu}_{2} \mathrm{O}$ shows the behavior of an $\mathrm{n}$-type semiconductor while the $\mathrm{p}-\mathrm{Cu}_{2} \mathrm{O}$ electrodeposited sample presented the behavior of a p-type semiconductor. The $\mathrm{p}-\mathrm{Cu}_{2} \mathrm{O} /$ $\mathrm{n}-\mathrm{Cu}_{2} \mathrm{O} / \mathrm{FTO}$ photoelectrode was successfully applied in photoelectrochemical assisted batch-injection analysis system for the determination of glucose in artificial saliva sample being a promising alternative method for glucose 
determination with good sensitivity, wide linear-response range, low limit of detection, and good sensitivity.

\section{Acknowledgments}

The authors are grateful to FAPEMA (INFRA-03186/18; UNIVERSAL-01057/19; UNIVERSAL-01194/17), CNPq (308204/2018-2; 309828/2020-1), Instituto Nacional de Ciência e Tecnologia em Bioanalítica (465389/2014-7), and FINEP for financial support. The authors gratefully acknowledge the Analytical Center of UFMA that provided the FTIR spectra.

\section{References}

1. Galant, A. L.; Kaufman, R. C.; Wilson, J. D.; Food Chem. 2015, $188,149$.

2. American Diabetes Association; Diabetes Care 2014, 37, S81.

3. Chen, S.; Qian, D.; Burström, K.; Burström, B.; Patient Educ. Couns. 2006, 103, 1767.

4. Lin, K.-D.; Hsu, C.-C.; Ou, H.-Y.; Wang, C.-Y.; Chin, M.-C.; Shin, S.-J.; JFMA 2019, 118, S103.

5. Xie, W.-Q.; Gong, Y.-X.; You, K.-X.; J. Chromatogr. A 2017, 150,143

6. Chen, X.; Chen, J.; Wang, F.; Xiang, X.; Luo, M.; Ji, X.; He, Z.; Biosens. Bioelectron. 2012, 35, 363.

7. Hull, E. L.; Metter, N. I.; Olson, B. P.; Ediger, M. N.; Magee, A. J.; Way, J. F.; Vugrin, K. E.; Maynard, J. D.; J. Clin. Transl. Endocrinol. 2014, 1, 92.

8. Meng, W.; Wen, Y.; Dai, L.; He, Z.; Wang, L.; Sens. Actuators, B 2018, 260, 852.

9. Xu, F.; Wu, M.; Ma, G.; Xu, H.; Shang, W.; Microchem. J. 2020, $159,105432$.

10. Li, J.; Chen, Q.; Bai, J.; Zhou, B.; J. Hazard Mater. 2013, 262, 304.

11. Liu, G.-Q.; Zhong, H.; Li, X.-R.; Yang, K.; Jia, F.-F.; Cheng, Z.-P.; Zhang, L.-L.; Yin, J.-Z.; Guo, L.-P.; Qian, H.-Y.; Sens. Actuators, B 2017, 242, 484.

12. Mahmoud, A.; Echabaane, C.; Omri, K.; Mir, L. E.; Chaabane, R. B.; J. Alloys Compd. 2019, 786, 960.

13. Tian, K.; Prestgard, M.; Tiwari, A.; Mater. Sci. Eng., C 2014, $41,100$.

14. Sehit, E.; Altintas, Z.; Biosens. Bioelectron. 2020, 159, 112165.

15. Zhang, Z.-X.; Zhao, C.-Z.; Chin. J. Anal. Chem. 2013, 41, 436.

16. Devadoss, A.; Sudhagar, P.; Terashima, C.; Nakata, K.; Fujishima, A.; J. Photochem. Photobiol., C 2015, 24, 43.

17. Zhao, W.-W.; Xu, J.-J.; Chen, H.-Y.; Biosens. Bioelectron. 2017, 92, 294.

18. Wang, S.; Li, S.; Wang, W.; Zhao, M.; Liu, J.; Feng, H.; Chen, Y.; Gu, Q.; Du, Y.; Hao, W.; Sens. Actuators, B 2019, 291, 34.

19. Saglam, O.; Dilgin, Y.; Electroanalysis 2017, 29, 1368.
20. Soares, L. C.; Santos, C. C.; Luz, R. C. S.; Damos, F. S.; Electroanalysis 2020, 32, 1608.

21. Wang, M.; Song, X.; Song, B.; Liu, J.; Hu, C.; Wei, D.; Wong, C.-P.; Sens. Actuators, B 2017, 250, 333.

22. Lin, L.-Y.; Karakocak, B. B.; Kavadiya, S.; Soundappan, T.; Biswas, P.; Sens. Actuators, B 2018, 259, 745.

23. Li, M.; Wang, H.; Wang, X.; Lu, Q.; Li, H.; Zhang, Y.; Yao, S.; Biosens. Bioelectron. 2019, 142, 111535.

24. Praveen, R.; Ramaraj, R.; J. Electroanal. Chem. 2019, 851, 113454.

25. Jayasingha, L.; Jayanthilaka, C.; Kumara, R.; Ohara, K.; Kaumal, M.; Gunewardene, S.; Dissanayake, D.; Jayanetti, S.; Electrochim. Acta 2020, 329, 135177.

26. Xiong, L.; Huang, S.; Yang, X.; Qiu, M.; Chen, Z.; Yu, Y.; Electrochim. Acta 2011, 56, 2735.

27. Xu, M.; Liu, X.; Xu, W.; Hao, X.; Feng, X.; J. Alloys Compd. 2018, 769, 484.

28. Wan, T.; Wei, Y.; Chang, X.; Li, C.; Li, A.; Liu, S.; Zhang, J.; Gong, J.; Appl. Catal., B 2018, 226, 31.

29. Gimenes, D. T.; Marra, M. C.; Freitas, J. M.; Muñoz, R. A. A.; Richter, E. M.; Sens. Actuators, B 2015, 212, 411.

30. Freitas, J. M.; Oliveira, T. C.; Gimenes, D. T.; Muñoz, R. A. A.; Richter, E. M.; Talanta 2016, 146, 670.

31. Tormin, T. F.; Narciso, L. C. D.; Richter, E. M.; Munoz, R. A. A.; Electrochim. Acta 2015, 164, 90.

32. Stefano, J. S.; Tormin, T. F.; da Silva, J. P.; Richter, E. M.; Munoz, R. A. A.; Microchem. J. 2017, 133, 398.

33. Pereira, P. F.; da Silva, W. P.; Munoz, R. A. A.; Richter, E. M.; J. Electroanal. Chem. 2016, 766, 87.

34. Mcshane, C. M.; Choi, K.-S.; Phys. Chem. Chem. Phys. 2012, 14,6112 .

35. Nishikawa, M.; Fukuda, M.; Nakabayashi, Y.; Saito, N.; Appl. Surf. Sci. 2016, 363, 173.

36. Rinaldi, A. L.; Rodríguez-Castellón, E.; Sobral, S.; Carballo, R.; J. Electroanal. Chem. 2019, 832, 209.

37. Ha, T.; Park, I.; Sim, K. I.; Lee, H.; Bae, J.-S.; Kim, S. J.; Kim, J. P.; Kim, T.-T.; Kim, J. H.; Jang, J. I.; Jeong, S.-Y.; APL Mater. 2019, 7, 031115.

38. Sahaia, A.; Goswamia, N.; Kaushikb, S. D.; Tripathic, S.; Appl. Surf. Sci. 2016, 390, 974.

39. Huang, Q.; Li, J.; Bi, X.; J. Alloys Compd. 2015, 647, 585.

40. Huang, M.-C.; Wang, T. H.; Chang, W.-S.; Lin, J.-C.; Wu, C.C.; Chen, I.-C.; Peng, K.-C.; Lee, S.-W.; Appl. Surf. Sci. 2014, $301,369$.

41. Mao, Y.; He, J.; Sun, X.; Li, W.; Lu, X.; Gan, J.; Liu, Z.; Gong, L.; Chen, J.; Liu, P.; Tong, Y.; Electrochim. Acta 2012, 62, 1.

42. Powell, D.; Compaan, A.; Macdonald, J. R.; Phys. Rev. B 1975, $12,20$.

43. Hossain, M. A.; Al-Gaashani, R.; Hamoudi, H.; Marri, M. J. A.; Hussein, I. A.; Belaidi, A.; Merzougui, B. A.; Alharbi, F. H.; Tabet, N.; Mater. Sci. Semicond. Process. 2017, 63, 203. 
44. Su, T.; Yang, Y.; Dong, G.; Ye, T.; Jiang, Y.; Fan, R.; RSC Adv. 2016, 6, 65125 .

45. Santos, G. K. C.; Silva, F. G. S.; Ferreira, A. R.; Luz, R. C. S.; Damos, F. S.; Microchem. J. 2019, 148, 424.

46. Meng, F.; Li, J.; Cushing, S. K.; Zhi, M.; Wu, N.; J. Am. Chem. Soc. 2013, 135, 10286.

47. Li, J.; Meng, F.; Suri, S.; Ding, W.; Huang, F.; Wu, N.; Chem. Commun. 2012, 48, 8213.

48. Wen, X.-J.; Niu, C.-G.; Zhang, L.; Zeng, G.-M.; Dalton Trans. 2017, 46, 4982 .

49. Tang, L.; Lv, J.; Kong, C.; Yang, Z.; Li, J.; New J. Chem. 2016, $40,6573$.
50. Li, Y.; Zhong, Y.; Zhang, Y.; Weng, W.; Li, S.; Sens. Actuators, B 2015, 206, 735 .

51. Liu, M.; Liu, R.; Chen, W.; Biosens. Bioelectron. 2013, 45, 206.

52. Long, M.; Tan, L.; Liu, H.; He, Z.; Tang, A.; Biosens. Bioelectron. 2014, 59, 243.

53. Yin, H.; Cui, Z.; Wang, L.; Nie, Q.; Sens. Actuators, B 2016 , $222,1018$.

54. Su, Y.; Guo, H.; Wang, Z.; Long, Y.; Li, W.; Tu, Y.; Sens. Actuators, B 2018, 255, 2510.

Submitted: May 23, 2021

Published online: August 30, 2021 